\title{
12. Inequality of opportunity and gender discrimination in China's labour income
}

\section{Jane Golley, Yixiao Zhou and Meiyan Wang}

Income inequality has been a persistent feature of China's rapid growth and development since the late 1970s. A vast literature has emerged to explain these inequalities along a number of dimensions, including regional and rural-urban disparities and intergenerational persistence in virtually all measures of 'economic advantage', be they per capita GDP, household income and wealth, individual earnings or educational attainment. ${ }^{1}$ While Deng Xiaoping famously justified these inequalities by arguing that some regions and people would need to become rich first before all could eventually prosper, he surely did not envisage, nor seek to justify, a gender divide in this argument-in which men would become rich first and women would only eventually prosper. Yet a growing body of evidence suggests that this gender divide not only exists, but also is widening.

A gender earnings gap has persisted in urban China throughout the reform periodand has, in fact, grown since the mid-1990s_-despite a narrowing of the gender gap in educational attainment in recent years, to the point where women now outeducate men, on average. ${ }^{2} \mathrm{~A}$ wide literature has confirmed that most of the earnings gap is attributable to gender discrimination, rather than observable factors such as gender differences in human capital or occupational choices. ${ }^{3}$ In rural China, gaps in both education and earnings are even more substantial. ${ }^{4}$ Rozelle et al. (2002) find that market reforms did little to affect the gender earnings gap in the rural economy, and they attribute much of the (relatively stable) gap between 1988 and 1995 to 'unexplained factors' or wage discrimination. Meng (1998), while finding some reduction in wage discrimination in the most marketised sectors of Chinese rural industry in the mid-1980s, found that it still accounted for twothirds of the wage differential in these sectors, leading her to conclude that China's

1 We cannot do justice to this literature here. See Knight (2014) and Zhou and Song (2016) for recent overviews; Gustafsson et al. (2008) and Li et al. (2013) for comprehensive discussions across many dimensions; Kanbur and Zhang (2005) and Golley (2007) on regional inequalities; Sicular et al. (2007) on rural-urban inequalities; Piketty et al. (2017) on wealth inequality; and Golley and Kong (2018) on intergenerational inequalities in education.

2 For evidence, see Golley and Kong (2018); Li (2010); and Zhang and Chen (2014).

3 See, for example, Li et al. (2011); Wang and Cai (2008); and Zhang et al. (2008a).

4 See, for example, Hannum et al. (2009); Zhang et al. (2007); and Zhang et al. (2012). 
gender wage discrimination was much more serious than in other industrial and developing economies. We have found no evidence to suggest that the situation for rural Chinese women has improved since then.

Female participation in the labour market has deteriorated during the reform period as well, with, for example, the urban female labour force participation rate dropping to 57 per cent in 2009 from 78 per cent in 1988 (Zhang et al. 2008a). Cook and Dong (2011) attribute this to the intensified pressures on women arising from their dual responsibilities as (unpaid) family carers and income earners during the economic transition. Zhang et al. (2008b) concur on this point, demonstrating that the observed gender earnings gap is strongly related to family status, with married women and mothers facing the most significant disadvantages in the (urban) labour market. Liu et al. (2010) likewise demonstrate the reduction in employment probability and hours of paid work for Chinese women, with the most striking costs being imposed by caring for one's parents-in-law, not one's own parents. The costs of child and elder care imposed on China's female labour force vary across urban, migrant and rural groups, but there is ample recent evidence that none of these groups is immune (Connelly et al. 2018; Ding et al. 2018; Song and Dong 2018).

There is also evidence of a growing gender bias in the political realm. During the 1980s and 1990s, women accounted for one-third of Communist Party members, while by 2017 they accounted for just one-quarter. Shu and Bian (2003) examine the importance of 'political capital'—proxied by Communist Party membershipas a determinant of the gender earnings gap. Noting that party members are more likely to be promoted and receive sponsorship for further education and training, they show that Communist Party membership was associated with earnings that were 6 per cent and 10 per cent higher for men and women, respectively, in 1995. However, the higher return for women did not reduce the earnings gap because of lower female membership numbers overall. Appleton et al. (2009) reveal an increasing wage reward for party membership_from 29 per cent in 1988 to 33 per cent in 1999-despite their initial expectations that they would fall, as market forces became more dominant. These findings suggest that party membership still matters for earnings, and it matters in different ways for men and for women.

Against this background, this chapter sets out to explore the factors that have contributed to inequality of opportunity in China's individual labour income, with a particular focus on gender. Inequality of opportunity is broadly defined as the component of overall inequality that can be explained by 'circumstances' beyond the control of an individual, as distinct from 'efforts' or choices that those individuals make. This distinction is crucial because, while inequality stemming from the latter can be justified as being fair and reasonable, inequality stemming from the formerfor example, being born male or female_cannot. We utilise the standard method in a burgeoning literature on inequality of opportunity to reveal that China's 
inequality of opportunity in labour income is alarmingly high. Furthermore, we show that gender is the number one determinant of unequal opportunities, ahead of socioeconomic, regional and urban-rural divides.

We complement this analysis with a more standard micro-level analysis of the underlying causes of gender earnings inequality. We use a standard OaxacaBlinder decomposition, in which differences between male and female incomes are apportioned into differences between male and female coefficients (the 'unexplained' portion, broadly interpreted as gender discrimination) and differences between male and female characteristics (the 'explained' portion), which comprise the circumstance and effort variables used in the inequality of opportunity analysis. ${ }^{5}$ This reveals that discrimination explains the dominant proportion of differences in average labour income between males and females, with gender differences in the rewards associated with marriage being the most significant contributing factor.

\section{Inequality of opportunity, circumstances and effort}

\section{Background}

The economic literature on 'inequality of opportunity' begins with the premise that the observed inequality in any particular economic outcome, or 'advantage', can be attributed to two components. The first component derives from the different circumstances in which individuals find themselves and over which they have no control-for example, their gender, place of birth or the socioeconomic status of their parents. The second derives from the different levels of effort that individuals may exert to influence a given outcome-for example, how hard they study, the occupation they choose or whether they choose to migrate or marry. This distinction is critical for assessing the extent to which equal opportunity does or does not prevail.

Roemer $(1993,1998)$ defines equal opportunity as a situation in which the distribution of a given outcome is independent of circumstances-that is, all individuals who exert the same level of effort will achieve the same outcome, regardless of their circumstances. Partitioning the population into groups of people—or 'types'-with identical circumstances and measuring the extent to which this condition is not satisfied provide one measure of inequality of opportunity. This involves suppressing 'intra-type' inequality (the inequality that can be explained by variation within each type, attributed to variation in 'effort') and calculating the extent of 'inter-type' inequality based on the mean levels for each type as an absolute measure of inequality

5 See Oaxaca (1973) and Blinder (1973), along with three examples of applications to China by Song et al. (2017), Su and Heshmati (2011) and Démurger et al. (2007). 
of opportunity. For comparability across different datasets and countries, it is more common to focus on the share of 'inter-type' inequality in overall inequality or the 'relative inequality of opportunity' (IOR).

A variety of empirical methods has been used to estimate inequality of opportunity for a wide range of outcomes, including household per capita income and consumption expenditure (as in Marrero and Rodríguez 2012); individual annual, monthly and long-run incomes (for example, by Bourguignon et al. 2007; Checchi et al. 2010; Björkland et al. 2012); educational attainment (as in the application to China in Golley and Kong 2016); and health outcomes (as in Jusot et al. 2013). Those focusing specifically on income inequality reveal significant variation in the share of inequality of opportunity in total income inequality (at both the household and the individual levels), ranging from close to one-third in Brazil and Guatemala (Ferreira and Gignoux 2011) to one-quarter for India (Singh 2012) and below 5 per cent in Norway, Denmark, Finland, Germany, the Netherlands and Slovakia (Marrero and Rodríguez 2012). ${ }^{6}$

While a number of different circumstances have been identified in these studies, a predominant set has emerged. These include father's (or parents') occupation and education; geographical location (region of birth, for single-country analyses; country of birth for cross-country ones); race, ethnicity or caste (in the case of India); and gender. Gender, however, has not been the primary focus in any of these works. Instead, for individual-level analyses, male-only samples tend to be used, with only a few exceptions. For example, Ferreira and Gignoux (2011) include gender as a circumstance in their analysis of individual labour earnings for five Latin American countries, and find that the share of overall inequality attributed to gender is smallfrom just 0.2 per cent in Colombia to 5.8 per cent in Guatemala-with other family background circumstances being more important, particularly parental education and father's occupation. De Barros et al. (2009) find a similar share for gender in the inequality of individual labour earnings in Mexico, at 3-4 per cent. Martinez et al. (2017) also use gender as a circumstance in their analysis of Australian individual income inequality between 2001 and 2013, revealing rising gender disparities over that period, but still a relatively small contribution of gender to overall income inequality, of less than 6 per cent (compared with more than 50 per cent for father's occupation-the most important circumstance). These small contributions contrast starkly with the dominant role we find for gender in the empirical analysis for China that follows.

In these cited works, the role of 'effort' has been largely overlooked, with the predominant estimation method (explained further below) subsuming this into the error term. One notable exception is Bourguignon et al. (2007), a much-cited

6 See Brunori et al. (2013) and Ferreira and Peragine (2015) for more comprehensive surveys of the methods used and results found. 
paper that examines individual (male) real hourly earnings across seven birth cohorts in Brazil. Their analysis explicitly considers the relationship between circumstances (race, region of birth, parental schooling and father's occupation) and three 'effort' variables - the individual's own schooling attainment, a migration dummy and a variable for labour market status_all of which are assumed to be determined, in turn, by circumstances. Despite some subsequent problems with the paper (conceded in a 2011 corrigendum), this paper was seminal in its attempt to identify both the direct effect of circumstances on earnings (or other outcomes) and the indirect effect as it operated through 'effort'.

\section{Measuring inequality of opportunity}

To formalise the ideas discussed above, we follow Roemer (1998) and begin with a finite population of individuals, $i \in\{1, \ldots, N\}$, each of whom has achieved an economic outcome (in our case, annual labour earnings), $y_{i}$, with distribution $\left\{y_{i}\right\}$. Earnings are assumed to be determined by a vector of circumstances, $C_{i}$, and a vector of efforts, $E_{i}$, which will be at least partially determined by circumstances, implying that $\mathrm{y}_{i}=f\left(C_{i} E_{i}\left(C_{i}, v_{i}\right), u_{i}\right)$. The sample population can then be divided into 'types', which by definition contain individuals with identical circumstances.

In principle, it is straightforward to calculate an absolute scalar measure of inequality of opportunity, $I O A$, by assigning to every individual the mean for their type (and thereby suppressing all intra-type inequality) and measuring the inequality in the distribution of those means using an appropriate index of inequality. The associated relative measure, $I O R$, is then $I O A$ as a share of total inequality. However, this simple nonparametric method requires a sample size far beyond what is available to us, or a significant reduction in the number of circumstances so as to limit the number of 'types' - a trade-off we are not willing to make. Instead, we use the standard parametric method, explained at length in Bourguignon et al. (2007) and Ferreira and Gignoux (2011), and summarised here.

We begin by approximating the relationship between earnings, circumstances and effort with the following structural forms (Equations 12.1 and 12.2).

\section{Equation 12.1}

$\ln \left(y_{i}\right)=a+b C_{i}+c E_{i}+u_{i}$

\section{Equation 12.2}

$E_{i}=d+e C_{i}+v_{i}$

Substituting Equation 12.2 into Equation 12.1 yields the reduced-form regression of Equation 12.3. 


\section{Equation 12.3}

$\ln \left(y_{i}\right)=\alpha+\beta C_{i}+\varepsilon_{i}$

In Equation 12.3, $\alpha=a+c d, \beta=b+c e, \varepsilon=c v_{i}+u_{i} ; y$ is labour earnings and $C$ is a vector of discrete circumstance variables, which can be partitioned into 'types'. Using the estimated coefficients, $\hat{\beta}$, and the actual values of circumstances, we construct a distribution, $\{\hat{y}\}$, where $\hat{y}_{i}=\exp \left[\hat{\boldsymbol{\beta}} \boldsymbol{C}_{\boldsymbol{i}}\right]$. By replacing each $y_{i}$ with its prediction, given the vector of circumstances (which is identical for all individuals of the same type), all intra-group inequality is eliminated, giving direct estimates of inequality of opportunity, $I O A=I(\{\hat{y}\})$ and $I O R=I(\{\hat{y}\}) / I(\{y\})$, where $I(\cdot)$ is an appropriate index of inequality. Following standard practice, we choose mean log deviation $\mathrm{GE}(0)$ as our inequality index. ${ }^{7}$

The vector of observed circumstances will only be a subset of all relevant circumstances that impact on individual earnings. As long as some unobserved circumstances are correlated with the observed circumstances (for example, IQ, which is almost certainly correlated with one's father's education and one's own earnings, but is not observed in the data), the estimated $\hat{\beta}$ coefficients will be biased and cannot be interpreted as causal links between a given circumstance and the outcome. However, for the overall measure of inequality of opportunity, this is not important: adding more circumstance variables to the observed set would necessarily increase the estimates of $I O A$ and $I O R$, implying that these are lower-bound estimates of the 'true' inequality of opportunity that would be measured if all circumstance variables could be observed (Ferreira and Gignoux 2011).

In addition to these overall measures, we are interested in the partial contributions of each of the circumstance variables. A number of papers have continued to use the method put forward by Bourguignon et al. (2007), despite their 2011 corrigendum in which they conceded the measure was flawed. We improve on this method by instead using a Shapley-value decomposition, which involves turning one variable (such as gender) 'on' or 'off' (for example, by setting at 'male' for all individuals) and assessing how the overall inequality measure varies accordingly. This method accounts for the well-known problem that inequality decompositions depend on the order in which inequality from a particular source is measured, and so uses a normalised average across all possible orderings for each source. That said, we recognise that these partial results should be treated with caution, given the biases already acknowledged above.

The above method suffices for calculating $I O A$ and $I O R$, and for identifying a set of circumstances that contribute to these. While this has become the dominant focus in the literature, there is more to learn from including some observable efforts in

7 For details on why this is the best measure, see Ferreira and Gignoux (2011). 
the modelling exercise, as done in the seminal paper by Bourguignon et al. (2007). Returning to the structural form presented in Equations 12.1 and 12.2, it is clear that an individual's labour earnings depend on his or her circumstances through two distinct channels: a direct channel (reflected in the coefficients on each circumstance in Equation 12.1); and an indirect channel, via the effect of his or her circumstances on his or her effort in Equation 12.2. Bourguignon et al. (2007) attempted to separately estimate these direct and indirect effects in their application to male earnings in Brazil, but subsequently conceded their results were not statistically sound. While this means that Equations 12.1 and 12.2 cannot be used in the way originally intended, they are still useful for illustrating the complex link between circumstances and some identifiable 'effort' variables_-and for demonstrating that these complex links work in different ways for different genders.

\section{Inequality of opportunity: Data and results}

\section{Data and baseline regressions}

We use the third wave of the Survey of Chinese Women's Social Status (2010), which is organised by the Women's Studies Institute of China, with joint sponsorship from the All-China Women's Federation and the National Bureau of Statistics of China. The complete database includes 29,694 observations from all 31 of China's provinces, each of which contains information on a randomly selected adult and child within each household. We choose annual labour income (or earnings) as our outcome of interest, including in the sample all individuals aged between 26 and 55 years of age with non-zero income. This yields a nationwide sample of 15,974 individuals. Individuals are divided into six age cohorts (from 26-30-yearolds through to 51-55-year-olds) to enable a comparison across those age groups (albeit not across time), which is the best available option for a single-country crosssectional dataset. $^{8}$

Drawing on the inequality of opportunity literature and the China-specific inequality literature cited above, we use the following set of circumstance variables for each of the six age cohorts:

1. Gender: male or female (female excluded in regressions).

2. Father's education: illiterate, primary school, junior high school and above (illiterate excluded).

8 The first and second waves of the Survey of Chinese Women's Social Status were completed in 1990 and 2000, respectively. If we are able to obtain these at a later stage, we will complement this work with analysis across two decades of reform. 
3. Father's occupation: agriculture (including forestry and fisheries), low-skilled non-agriculture, high-skilled non-agriculture (agriculture excluded).

4. Hukou (household registration) status at birth: rural or urban (rural excluded).

5. Region: east, central and west (west excluded)..$^{10}$

In combination, this implies that for each age cohort we are dealing with 108 types, in the 'comfortable' range of 72-108 types, according to Ferreira and Peragine (2015). For example, one type (a relatively 'unlucky' one, as it turns out) comprises rural females born in western China with illiterate fathers who work in agriculture. In the nationwide regressions for the entire sample, age cohorts are included as the sixth 'circumstance'-as one clearly cannot choose the year in which they are born.

We draw on Bourguignon et al. (2007) and the data available in the survey, to propose the following five 'effort' variables:

1. Own education: a dummy variable for those who have attained junior high or below, or senior high school and above.

2. Own occupation: a dummy variable representing those who work in the agricultural or non-agricultural sector.

3. Migration: a dummy variable for those who have 'ever worked or ran a business in a town or city different from where your hukou is for more than half a year' or who have 'never migrated'.

4. Communist Party membership (dummy variable for yes or no).

5. Marital status (married or not married, with the latter including people who have never married, are divorced or whose spouse has died).

One's own education is included to reflect the fact that schooling above junior high has never been compulsory in China, and to some extent reflects an individual's choice (although, as it turns out, a substantial part of that choice, or 'effort', is explained by one's circumstances). Likewise, it is also a matter of choice, to some extent at least, to migrate and/or work in occupations outside the agricultural sector. Communist Party membership is included to reflect the effort required to gain such membership, which may relate to one's political connections (guanxi), alongside the reasons identified by Shu and Bian (2003) and Appleton et al. (2009). The inclusion of marital status is in recognition of the fact that couples have interdependent

9 The survey includes village, town, town-city and city; 'rural' is equated with 'village', while the others are all classified as 'non-rural'.

10 We use the standard regional classifications for this. Ideally, we would have region of birth as this variable, but this is not available in the survey, so we use region identified at the time of the survey. While this is problematic in the sense that some people will have migrated since birth (a matter of choice, not circumstance), this only accounts for 9 per cent of the surveyed individuals. We considered this a reasonable sacrifice given the significant regional variations in levels of development across China and the standard practice of including 'region' as a circumstance in the comparable literature. 
preferences that affect their household income decisions, in ways that often imply different employment choices for men and women, as shown in Zhang et al. (2008b) in the case of China. ${ }^{11}$

Table 12.1 presents the summary statistics for the nationwide sample and the female and male subsamples. Nearly everything is consistent with expectations. In terms of circumstances, people born in urban areas in eastern China, who have moreeducated fathers in non-agricultural occupations out-earn those in relevant categories 'below' them, and average earnings fall across the age range, consistent with higher average educational attainments among younger generations. One outlier is that average income in the western region is higher than in the centre-underpinned by higher female (but not male) income in the west. In terms of 'effort', higher levels of education, non-agricultural occupations, Communist Party membership and nonmigration are associated with higher income (because almost all migrants are from rural areas, where earnings are lower). Notably, marriage is associated with higher average income for men, but lower income for women - a point we return to below.

Table 12.1 Preliminary statistics: Labour income by gender, circumstance and 'effort'

\begin{tabular}{|c|c|c|c|c|}
\hline & Nationwide & Females & Males & $\begin{array}{c}\text { Female/male } \\
\text { ratio }\end{array}$ \\
\hline Number of individuals & 15,974 & 7,592 & 8,382 & \\
\hline Mean labour income (RMB) & 19,696 & 15,241 & 23,730 & 0.64 \\
\hline \multicolumn{5}{|l|}{ CIRCUMSTANCE VARIABLES } \\
\hline \multicolumn{5}{|l|}{ Father's education } \\
\hline Illiterate & 12,877 & 8,658 & 16,374 & 0.53 \\
\hline Primary school & 18,785 & 12,922 & 23,975 & 0.54 \\
\hline Junior high and above & 26,090 & 22,435 & 29,732 & 0.75 \\
\hline \multicolumn{5}{|l|}{ Father's occupation } \\
\hline Agriculture, forestry and fishery & 15,532 & 11,481 & 19,223 & 0.60 \\
\hline Low-skill non-agricultural & 26,195 & 21,647 & 30,113 & 0.72 \\
\hline High-skill non-agricultural & 30,760 & 23,864 & 37,407 & 0.64 \\
\hline \multicolumn{5}{|l|}{ Born in } \\
\hline Rural & 16,843 & 12,220 & 21,070 & 0.58 \\
\hline Urban & 26,512 & 22,583 & 29,992 & 0.75 \\
\hline \multicolumn{5}{|l|}{ Birth region } \\
\hline East & 24,089 & 18,083 & 29,164 & 0.62 \\
\hline Central & 15,149 & 11,056 & 18,994 & 0.58 \\
\hline West & 16,432 & 14,550 & 18,277 & 0.80 \\
\hline
\end{tabular}

11 We leave aside the (important) debate as to whether Becker's $(1974,1976,1991)$ view of these choices is credible or not (as made clear in Bergmann 1995; and Woolley 1996). For our purposes, it suffices to say that marriage has notably different associations with the earnings of women and men, as seen below. 


\begin{tabular}{|c|c|c|c|c|}
\hline & Nationwide & Females & Males & $\begin{array}{c}\text { Female/male } \\
\text { ratio }\end{array}$ \\
\hline \multicolumn{5}{|l|}{ Age cohorts } \\
\hline $26-30$ & 27,477 & 23,660 & 31,162 & 0.76 \\
\hline $31-35$ & 22,128 & 16,557 & 27,984 & 0.59 \\
\hline $36-40$ & 18,949 & 15,456 & 22,358 & 0.69 \\
\hline $41-45$ & 18,589 & 14,301 & 22,777 & 0.63 \\
\hline $46-50$ & 17,703 & 12,547 & 22,108 & 0.57 \\
\hline $51-55$ & 15,714 & 9,477 & 19,572 & 0.48 \\
\hline \multicolumn{5}{|l|}{ EFFORT VARIABLES } \\
\hline \multicolumn{5}{|l|}{ Own education } \\
\hline Junior high or below & 13,531 & 9,372 & 17,662 & 0.53 \\
\hline Senior high school and above & 29,029 & 25,296 & 31,966 & 0.79 \\
\hline \multicolumn{5}{|l|}{ Own occupation } \\
\hline Agriculture, forestry and fishery & 8,566 & 6,327 & 11,055 & 0.57 \\
\hline Non-agricultural & 26,011 & 21,210 & 29,879 & 0.71 \\
\hline \multicolumn{5}{|l|}{ Political party } \\
\hline $\begin{array}{l}\text { No Communist Party } \\
\text { membership }\end{array}$ & 18,126 & 14,107 & 22,117 & 0.64 \\
\hline Communist Party member & 28,577 & 24,506 & 30,722 & 0.80 \\
\hline \multicolumn{5}{|l|}{ Migration status } \\
\hline Ever migrated & 18,387 & 10,779 & 24,161 & 0.45 \\
\hline Never migrated & 19,818 & 15,618 & 23,686 & 0.66 \\
\hline \multicolumn{5}{|l|}{ Marital status } \\
\hline Married & 19,543 & 14,867 & 23,828 & 0.62 \\
\hline Not married & 21,235 & 19,294 & 22,800 & 0.85 \\
\hline
\end{tabular}

Notes: Sample includes all surveyed individuals with non-zero labour income. 'Non-agricultural low-skill occupations' include craft and related trade workers, service and sales workers and clerical support. 'Non-agricultural high-skill occupations' include professionals and managers. 'Rural' is equated with 'village' and 'urban' with all other classifications: town, town-city and city.

Sources: Survey of Chinese Women's Social Status (2010) and authors' calculations.

What is most striking in Table 12.1 is the gender difference, summarised by the female/male earnings ratios in the final column. Gender inequality exists for every circumstance and at both ends of the socioeconomic spectrum-although the ratios are noticeably lower at the lower end of the spectrum. Some of these disparities may reflect the fact that women work fewer hours, which, given different retirement ages, is certainly the case for the oldest cohort, which has the lowest female/ male earnings ratio of just 0.48 . Another explanation is likely to be the different occupational structures for men and women-for example, 40 per cent of women work in agriculture, compared with 28 per cent of men (on which more below). But this is not the whole story. And even if it was, it would still point to inequality of opportunity in annual labour, which is an important story in its own right. 
Table 12.2 presents the regression results for the nationwide sample, with Column 1 including only the circumstance variables, as in Equation 12.3, and Column 2 extending this to include the 'effort' variables as well, as in Equation 12.1. As seen in Column 1, being male is associated with labour earnings that are $0.54 \mathrm{log}$ points higher than females. ${ }^{12}$ All coefficients take on their expected signs and relative magnitudes - for example, they are increasing with father's education and occupation, with urban hukou status and from west to east. The age profile now exhibits the expected inverted-U shape (in contrast with the raw data).

Table 12.2 Determinants of labour earnings: Circumstance and effort

\begin{tabular}{|c|c|c|c|c|}
\hline Independent variables & Equation 12.3 & Equation 12.1 & Equation 12.1 & Equation 12.1 \\
\hline Circumstance variables & & & Females & Males \\
\hline Male & $0.54^{\star \star \star}$ & $0.44^{\star \star \star}$ & & \\
\hline Father primary & $0.22^{\star \star \star}$ & $0.11^{\star \star \star}$ & $0.11^{\star \star \star}$ & $0.12^{\star \star \star}$ \\
\hline Father junior high and above & $0.34^{\star \star \star}$ & $0.14^{\star \star \star}$ & $0.15^{\star \star \star}$ & $0.13^{\text {*** }}$ \\
\hline Father low-skill non-agricultural & $0.30^{\star \star \star *}$ & 0.035 & $0.057^{*}$ & 0.017 \\
\hline Father high-skill non-agricultural & $0.41^{\star \star \star}$ & $0.13^{\star \star \star}$ & $0.13^{\star \star \star}$ & $0.14^{\star * \star}$ \\
\hline Urban & $0.35^{\star \star \star}$ & $0.058^{\star *}$ & $0.10^{\star \star \star}$ & 0.016 \\
\hline Central region & $0.09^{\star \star *}$ & $0.02^{\star \star \star}$ & $-0.07^{\star \star \star}$ & $0.12^{\star \star \star}$ \\
\hline Eastern region & $0.42^{\star \star \star}$ & $0.29^{\star \star \star}$ & $0.18^{\star \star \star}$ & $0.40^{\star \star \star}$ \\
\hline Age dummies & YES & YES & YES & YES \\
\hline \multicolumn{5}{|l|}{ Effort variables } \\
\hline Non-agricultural occupation & & $0.76^{\star \star \star}$ & $0.79^{\star \star \star}$ & $0.72^{\star \star \star}$ \\
\hline Senior high and above & & $0.38^{\star \star \star}$ & $0.44^{\star \star \star}$ & $0.31^{\star \star \star}$ \\
\hline Communist Party membership & & $0.20^{\star \star \star}$ & $0.22^{\star \star \star}$ & $0.19^{\star \star *}$ \\
\hline Migration & & $0.092^{\star \star \star}$ & 0.023 & $0.14^{\star \star \star}$ \\
\hline Married & & $0.16^{\star \star \star}$ & 0.065 & $0.26^{\star \star \star}$ \\
\hline Constant & $8.9^{\star \star \star}$ & $8.34^{\star \star \star}$ & $8.35^{\star \star \star}$ & $8.81^{\star \star \star}$ \\
\hline Observations & 15,974 & 15,974 & 7,592 & 8,382 \\
\hline Adjusted $\mathrm{R}^{2}$ & 0.248 & 0.400 & 0.392 & 0.337 \\
\hline
\end{tabular}

${ }^{*} \mathrm{p}<0.05^{* *} \mathrm{p}<0.01{ }^{* * *} \mathrm{p}<0.005$

Sources: Survey of Chinese Women's Social Status (2010) and authors' calculations.

As seen in Column 2, adding in the effort variables yields a considerable increase in the adjusted R-squared values, with the bulk of this increase coming from own occupation and own education, and only minor increases for Communist Party

12 For the log-linear form, the difference between the excluded dummy, $x$ (e.g. male), and the included one, $y$ (e.g. female), is given by $\ln (x)-\ln (y)=\ln (x / y)$. If $x$ differs from $y$ by a factor of $1+e$, then $\ln (x / y)=\ln (1+e)$, which is approximately $e$, the percentage difference between $x$ and $y$, but only when $e$ is small. The exact percentage change is given by $\exp (e-1)$, which for the example given here amounts to 75 per cent. 
membership, migration and marriage. ${ }^{13}$ Working in a non-agricultural occupation is associated with earnings that are $0.68 \mathrm{log}$ points higher than working in agriculture, while having senior high school education or above is associated with a $0.35 \mathrm{log}$ point income boost. The coefficients on Communist Party membership and migration are positive and significant, but small.

As expected, coefficients on many of the circumstances fall compared with those in Column 1-an indication of the correlations between these and the two key effort variables of own education and own occupation (although none is too high to suggest multicollinearity as a serious problem). For example, the coefficient on having a father with more than junior high education falls from 0.41 to 0.14 due to the correlation between this and one's own education. Being male continues to have the highest positive association with income for the nationwide sample.

Columns 3 and 4 present the results for the female and male subsamples, respectively. The substantial gender differences seen in Table 12.1 are confirmed even with all controls added. The adjusted R-squared for the female subsample is considerably higher than for men, and the same is true when only circumstances are included in the regression (not presented here for space reasons). This provides the first indication that women's earnings are affected (that is, constrained) more by their circumstances than men's. This is also suggested by the higher magnitudes of most coefficients in the female regressions - more than double that for men for being born 'urban' and with higher returns for having educated fathers working outside agriculture as well.

The rewards for women associated with putting in the 'effort' to leave agriculture, attain senior high education and gain Communist Party membership are all higher than for men, while migration and marriage offer no significant returns for women, but do for men. The key point is that all of these circumstance and effort variables matter, and they matter in different ways for the two genders.

To calculate the inequality of opportunity in labour income, we focus on Equation 12.3 using the method described above. We are also interested in how this varies across age cohorts, so we first present, in Table 12.3, the baseline results for each age cohort. This confirms the significance of being male for all cohorts, with higher coefficients for older cohorts. Given the cross-sectional nature of the data, it is impossible to say whether this is because of an improvement in gender biases in income for younger cohorts or a deterioration with age as the circumstance of being male culminates in higher rewards.

13 In regressions adding these effort variables separately to the nationwide sample, the adjusted R-squared increases from 0.248 (Column 1, Table 12.2) to 0.367 for one's own occupation; 0.310 for one's own education; 0.272 for Communist Party membership; 0.250 for marriage; and negligible for migration. 
Table 12.3 'Circumstantial' determinants of labour income by age cohort

\begin{tabular}{|c|c|c|c|c|c|c|}
\hline Cohort & $26-30$ & $31-35$ & $36-40$ & $41-45$ & $46-50$ & $51-55$ \\
\hline \multicolumn{7}{|l|}{ Independent variables } \\
\hline Male & $0.42^{\star \star \star}$ & $0.49^{\star \star \star}$ & $0.51^{\star \star \star}$ & $0.51^{\star \star \star}$ & $0.61^{\star \star \star}$ & $0.69^{* \star *}$ \\
\hline Father primary & $0.21^{\star *}$ & $0.28^{\star \star \star}$ & $0.24^{\star \star \star}$ & $0.24^{\star \star \star}$ & $0.18^{\star \star \star}$ & $0.22^{\star * \star}$ \\
\hline Father junior high and above & $0.33^{\star \star *}$ & $0.45^{\star \star \star}$ & $0.40^{\star \star \star}$ & $0.40^{\star \star \star}$ & $0.29^{\star \star \star}$ & $0.21^{\star \star}$ \\
\hline Father low-skill non-agricultural & $0.46^{\star \star \star}$ & $0.35^{\star \star \star}$ & $0.28^{\star * *}$ & $0.28^{\star \star \star}$ & $0.16^{\star \star}$ & $0.27^{* \star *}$ \\
\hline Father high-skill non-agricultural & $0.61^{\star \star \star}$ & $0.44^{\star \star \star}$ & $0.46^{\star \star \star}$ & $0.46^{\star \star \star}$ & $0.34^{\star \star \star}$ & $0.34^{\star \star \star}$ \\
\hline Urban & $0.25^{\star \star \star}$ & $0.30^{\star \star \star}$ & $0.28^{\star \star \star}$ & $0.28^{\star \star \star}$ & $0.36^{\star \star \star}$ & $0.58^{\star \star \star}$ \\
\hline Central region & $0.04^{\star \star \star}$ & $0.11^{\star \star \star}$ & $0.10^{\star \star \star}$ & $0.10^{\star \star \star}$ & $0.10^{\star \star \star}$ & $0.09^{\star \star *}$ \\
\hline Eastern region & $0.45^{\star \star \star}$ & $0.48^{\star \star \star}$ & $0.40^{\star \star \star}$ & $0.40^{\star \star \star}$ & $0.45^{\star \star \star}$ & $0.37^{* \star *}$ \\
\hline Constant & 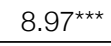 & $8.96^{\star \star \star}$ & $8.89^{\star \star \star}$ & $8.89^{\star \star \star}$ & $8.83^{\star \star \star}$ & $8.43^{\star \star \star}$ \\
\hline Observations & 1,889 & 2,336 & 3,460 & 3,460 & 2,839 & 2,125 \\
\hline Adjusted $\mathrm{R}^{2}$ & 0.249 & 0.261 & 0.231 & 0.231 & 0.232 & 0.279 \\
\hline
\end{tabular}

${ }^{*} p<0.05$ ** $p<0.01{ }^{* \star *} p<0.005$

Sources: Survey of Chinese Women's Social Status (2010) and authors' calculations.

We use the regression results in Column 1 of Table 12.2 and all of Table 12.3 to calculate the inequality of opportunity in China's labour income. These results are presented in Table 12.4. The top two rows provide scalar measures of inequality in labour income using $\mathrm{GE}(0)$ and the Gini coefficient, for the nationwide sample and for each cohort. Gini coefficients are included to stress the point that income inequality across this sample is undeniably high-above 0.5 in all but two of the age cohort subsamples.

Table 12.4 Inequality of opportunity in labour income and decomposition by circumstance

\begin{tabular}{|c|c|c|c|c|c|c|c|}
\hline & \multirow[t]{2}{*}{ All } & \multicolumn{6}{|c|}{ By birth cohort } \\
\hline & & $26-30$ & $31-35$ & $36-40$ & $41-45$ & $46-50$ & $51-55$ \\
\hline \multicolumn{8}{|l|}{ Total inequality } \\
\hline Mean log deviation (GE(O)) & 0.55 & 0.70 & 0.50 & 0.46 & 0.52 & 0.51 & 0.62 \\
\hline Gini & 0.53 & 0.59 & 0.51 & 0.55 & 0.52 & 0.51 & 0.56 \\
\hline \multicolumn{8}{|l|}{ Inequality of opportunity } \\
\hline Absolute (IOA) & 0.14 & 0.14 & 0.14 & 0.12 & 0.07 & 0.13 & 0.13 \\
\hline \multirow[t]{2}{*}{ Relative (IOR) } & 0.25 & 0.20 & 0.28 & 0.26 & 0.14 & 0.25 & 0.21 \\
\hline & \multicolumn{7}{|c|}{ Shapley-value decomposition (contribution to IOA, \%) } \\
\hline Gender & 28 & 30.0 & 34.2 & 22.6 & 38.0 & 37.9 & 32.4 \\
\hline Father education type & 18 & 10.0 & 14.4 & 20.0 & 13.5 & 11.9 & 12.9 \\
\hline Father occupation type & 18 & 31.3 & 22.7 & 22.8 & 17.7 & 13.1 & 16.0 \\
\hline Born rural or not & 9 & 1.9 & 7.3 & 13.0 & 18.3 & 7.2 & 17.5 \\
\hline
\end{tabular}




\begin{tabular}{|c|c|c|c|c|c|c|c|}
\hline & \multirow[t]{2}{*}{ All } & \multicolumn{6}{|c|}{ By birth cohort } \\
\hline & & $26-30$ & $31-35$ & $36-40$ & $41-45$ & $46-50$ & $51-55$ \\
\hline Region & 18 & 24.9 & 21.5 & 21.7 & 12.5 & 29.9 & 21.2 \\
\hline Age cohort & 10 & & & & & & \\
\hline
\end{tabular}

Sources: Survey of Chinese Women's Social Status (2010) and authors' calculations.

The IOR provides the best gauge in terms of international comparisons to assert the point that the share of inequality of opportunity in total inequality in China's individual labour income is unquestionably high-with an $I O R$ value of 0.25 (or 25 per cent) for the nationwide sample, and with all cohort-level IORs above 0.2 , with just one exception. This in itself is a major concern. But what is even more worrying are the Shapley-value decompositions, which reflect the partial contributions from each of the circumstances to the overall IOA (or IOR). These reveal that gender is the circumstance with the single largest contribution to inequality of opportunity in individual labour income, accounting for 28 per cent of the nationwide IOA (Column 1). This is followed by one's region, father's occupation, father's education, birth cohort and being rural or urban, in that order. For four of the six birth cohorts, gender is the largest contributor to inequality of opportunity, peaking at 38 per cent for the 41-45-year-old cohort. It ranks second for the two remaining cohorts (ages 26-30 and 36-40) - below father's occupation in both cases. Even if these calculations are biased by omitted variables-as they undoubtedly are-and reflect to some extent women's 'choices' about labour market participation, occupations and hours worked, as well as other unobserved characteristics that make men and women different, we argue that this finding should be taken seriously and investigated further.

One way of pushing the importance of gender further is to consider the relationship between each 'effort' variable and circumstances and how these differ across the male and female subsamples. Table 12.5 presents the results of probit regressions for each of the binary effort variables conditioned on the set of circumstance variables, as in Equation 12.2. Nearly all coefficients take on their expected signs and relative magnitudes. For example, as seen in Columns 1 and 2 for all three panels, individuals with more educated fathers in non-agricultural occupations are likely to be more educated and work in non-agricultural occupations themselves. Columns 4 and 5 of Panel A reveal that men are more likely to migrate but less likely to be married than women (reflecting the unbalanced sex ratio). Critically, the pseudo R-squared values are highest for the own education and own occupation regressions in Columns 1 and 2, and both of these are higher for the female subsample (in Panel B) than the male subsample (in Panel C), underpinned by larger magnitudes on just about all coefficients in the female subsample regressions. This indicates that circumstances matter more for women, not only directly (in that they are essentially penalised for their gender), but also indirectly, through their effect on prominent and identifiable forms of 'effort'. 
Table 12.5 Probit regressions of 'efforts' determined by circumstances

\begin{tabular}{|c|c|c|c|c|c|}
\hline Circumstances & $\begin{array}{c}\text { Own } \\
\text { education }\end{array}$ & $\begin{array}{c}\text { Own } \\
\text { occupation }\end{array}$ & $\begin{array}{c}\text { Communist } \\
\text { Party } \\
\text { membership }\end{array}$ & Migration & Marriage \\
\hline & \multicolumn{5}{|c|}{ Panel A: Nationwide } \\
\hline Male & $0.20^{\star \star \star}$ & $0.28^{\star \star \star}$ & $0.37^{\star \star \star}$ & $0.14^{\star \star \star}$ & $-0.063^{\star}$ \\
\hline Father primary & $0.33^{\star \star \star}$ & $0.20^{\star \star \star}$ & $0.24^{\star \star \star}$ & 0.013 & $0.16^{\star \star \star}$ \\
\hline Father junior high and above & $0.75^{\star \star \star}$ & $0.35^{\star \star \star}$ & $0.48^{\star \star \star}$ & $-0.11^{*}$ & $0.15^{\star \star \star}$ \\
\hline Father low-skill non-agricultural & $0.49^{\star \star \star}$ & $1.15^{\star \star \star}$ & $0.12^{\star \star \star}$ & $-0.25^{\star \star \star}$ & $-0.14^{\star \star \star}$ \\
\hline Father high-skill non-agricultural & $0.71^{\star \star *}$ & $0.78^{\star \star \star}$ & $0.30^{\star \star \star}$ & $-0.22^{\star \star \star}$ & -0.068 \\
\hline Urban & $0.74^{\star \star \star}$ & $1.25^{\star \star \star}$ & $0.20^{\star \star \star}$ & $-0.87^{\star \star \star}$ & $-0.38^{\star * \star}$ \\
\hline Central region & $0.11^{\star *}$ & $0.21^{\star \star *}$ & 0.11 & $0.05^{\star \star \star}$ & 0.199 \\
\hline Eastern region & $0.19^{\star \star \star}$ & $0.49^{\star \star \star}$ & $0.091^{\star *}$ & $-0.16^{\star \star \star}$ & $0.13^{\star \star \star}$ \\
\hline Observations & 15,974 & 15,974 & 15,974 & 15,974 & 15,974 \\
\hline \multirow[t]{2}{*}{ Pseudo $\mathrm{R}^{2}$} & 0.214 & 0.280 & 0.059 & 0.097 & 0.062 \\
\hline & \multicolumn{5}{|c|}{ Panel B: Female } \\
\hline Father primary & $0.32^{\star \star \star}$ & $0.28^{\star \star \star}$ & $0.27^{\star \star \star}$ & 0.071 & 0.082 \\
\hline Father junior high and above & $0.77^{\star \star \star}$ & $0.44^{\star \star \star}$ & $0.52^{\star \star \star}$ & -0.064 & 0.026 \\
\hline Father low-skill non-agricultural & $0.63^{\star \star *}$ & $1.07^{\star \star \star}$ & $0.22^{\star \star \star}$ & $-0.27^{\star \star \star}$ & $-0.21^{\star \star \star}$ \\
\hline Father high-skill non-agricultural & $0.75^{\star \star \star}$ & $0.76^{\star \star \star}$ & $0.30^{\star \star \star}$ & $-0.29^{\star \star}$ & -0.099 \\
\hline Urban & $0.87^{\star \star \star}$ & $1.30^{\star \star \star}$ & $0.34^{\star \star \star}$ & $-0.81^{\star \star \star}$ & $-0.48^{\star \star \star}$ \\
\hline Central region & $0.05^{\star \star}$ & $0.15^{\star \star \star}$ & 0.027 & $0.13^{\star \star \star}$ & $0.16^{\star \star}$ \\
\hline Eastern region & $0.16^{\star \star *}$ & $0.53^{\star \star \star}$ & 0.082 & $-0.16^{\star \star}$ & -0.0046 \\
\hline Observations & 7,592 & 7,592 & 7,592 & 7,592 & 7,592 \\
\hline \multirow[t]{2}{*}{ Pseudo $\mathrm{R}^{2}$} & 0.269 & 0.303 & 0.072 & 0.099 & 0.071 \\
\hline & \multicolumn{5}{|c|}{ Panel C: Male } \\
\hline Father primary & $0.35^{\star \star *}$ & $0.13^{\star \star \star}$ & $0.24^{\star \star *}$ & -0.030 & $0.21^{\star \star \star}$ \\
\hline Father junior high and above & $0.73^{\star \star *}$ & $0.27^{\star \star \star}$ & $0.46^{\star \star \star}$ & $-0.14^{*}$ & $0.25^{\star \star \star}$ \\
\hline Father low-skill non-agricultural & $0.38^{\star \star *}$ & $1.25^{\star \star \star}$ & 0.052 & $-0.23^{\star \star \star}$ & -0.087 \\
\hline Father high-skill non-agricultural & $0.68^{\star \star \star}$ & $0.81^{\star \star \star}$ & $0.31^{\star \star \star}$ & -0.17 & -0.030 \\
\hline Urban & $0.62^{\star \star \star}$ & $1.20^{\star \star \star}$ & $0.093^{\star}$ & $-0.91^{\star \star \star}$ & $-0.33^{\star \star \star}$ \\
\hline Central region & 0.15 & $0.27^{\star \star \star}$ & 0.17 & $-0.03^{\star \star}$ & 0.227 \\
\hline Eastern region & $0.21^{\star \star \star}$ & $0.46^{\star \star \star}$ & $0.099^{\star}$ & $-0.17^{\star \star \star}$ & $0.24^{\star \star \star}$ \\
\hline Observations & 8,382 & 8,382 & 8,382 & 8,382 & 8,382 \\
\hline Pseudo $\mathrm{R}^{2}$ & 0.172 & 0.256 & 0.037 & 0.097 & 0.075 \\
\hline
\end{tabular}

${ }^{* \star *} p<0.01^{* \star} p<0.05^{*} p<0.1$

Sources: Survey of Chinese Women's Social Status (2010) and authors' calculations. 


\section{From inequality of opportunity to gender discrimination}

To further analyse the underlying causes of gender income inequality, we apply an Oaxaca-Blinder decomposition to the estimate of Equation 12.1, which is essentially an extended Mincer-type equation in which the combined set of circumstance and 'effort' variables comprises the individual characteristics that determine one's own income. ${ }^{14}$ This apportions differences between male and female labour incomes into two parts: first, the differences between the male and female coefficients in two separate regressions for the male and female subsamples (as seen in the last two columns of Table 12.2 for the nationwide sample), ${ }^{15}$ which form the 'unexplained' portion, used as a proxy for gender discrimination; and second, differences between male and female characteristics (the 'explained' portion), such as different levels of educational attainment.

Specifically, the gender earnings gap is the difference between average male income and average female income (Equation 12.4).

\section{Equation 12.4}

$G=\overline{\ln y}\left(x_{m} ; \gamma_{m}\right)-\overline{\ln y}\left(x_{f} ; \gamma_{f}\right)=D+E$

In Equation 12.4, $\gamma_{m}$ is the vector of coefficients in Equation 12.1 for the male-only sample and $\gamma_{f}$ is that for the female-only sample, ${ }^{16} D=\overline{\ln y}\left(x_{m} ; \gamma_{m}\right)-\overline{\ln y}\left(x_{m} ; \gamma_{f}\right)$ and $E=\overline{\ln y}\left(x_{m} ; \gamma_{f}\right)-\overline{\ln y}\left(x_{f} ; \gamma_{f}\right)$.

This decomposition corresponds to an evaluation of what the observed male/female income gap would be under the following conditions:

1. If men and women share the same sociodemographic characteristics (that of men in Equation 12.1), D is the pure difference-in-coefficients (or discrimination) effect.

2. If men and women face the same remuneration structure (that of women in Equation 12.1), E is the pure difference-in-characteristics effect.

14 The approach taken here is similar to that in Démurger et al. (2007).

15 A slight difference is that the regressions used for this decomposition categorise an individual's occupation to be consistent with those for father's occupation. This is because there are too few urban people working in agriculture (the dummy chosen for own occupation in Table 12.2). The more refined set of categories here is thus required for the urban and rural analyses, which adds an important dimension to our story, as seen below.

$16 \gamma_{m}$ and $\gamma_{f}$ correspond to the coefficients $a, b$ and $c$ in Equation 12.1 for the male-only sample and the femaleonly sample, respectively. 
We further decompose both the pure discrimination effect, D, and the pure difference-in-characteristics effect, $\mathrm{E}$, into contributions from each of the variables included in the regressions for the nationwide sample (as seen in Table 12.2), as well as for the urban and rural subsamples. ${ }^{17}$

Table 12.6 presents the decomposition results. The first point to make is that discrimination - that is, income differences stemming from differences in coefficients rather than characteristics-explains the dominant proportion of the nationwide gender gap, accounting for 86.8 per cent of the (log) income differential, with the remaining 14.6 per cent attributed to differences in characteristics. For the latter, the shares attributable to individual variables reveal dominant contributions from men's higher average levels of education and greater likelihood of being employed in non-agricultural occupations. In terms of the discrimination, one's marital status is associated with significantly higher income for males than females (accounting for 37.8 per cent of the discrimination effect, respectively), while differences in the returns to education and non-agricultural employment actually work in women's favour (with shares of -8.1 and -11.9 per cent, respectively).

Table 12.6 Oaxaca-Blinder decomposition of gender labour income differential

\begin{tabular}{|c|c|c|c|}
\hline & Nationwide & Urban & Rural \\
\hline \multicolumn{4}{|l|}{ Observed Ln labour income } \\
\hline Men & 9.59 & 9.95 & 9.44 \\
\hline Women & 9.06 & 9.66 & 8.82 \\
\hline Differential & 0.53 & 0.29 & 0.62 \\
\hline \multicolumn{4}{|l|}{ Decomposition shares (\%) } \\
\hline Difference in characteristics & 14.6 & -13.6 & 19.1 \\
\hline Discrimination & 86.8 & 109.3 & 84.6 \\
\hline \multicolumn{4}{|c|}{ Share in difference-in-characteristics effect (\%) } \\
\hline Age & $-16.9^{\star \star \star}$ & 25.2 & $-7.9^{\star \star \star}$ \\
\hline Own education & $25.0^{\star \star \star}$ & 24.0 & $24.5^{\star \star \star}$ \\
\hline Own occupation & $70.3^{\star \star \star}$ & $56.3^{\star \star}$ & $69.2^{\star \star \star}$ \\
\hline Migration & 0.6 & 0.0 & 0.0 \\
\hline Married & -0.9 & -3.5 & -1.4 \\
\hline Communist Party membership & $16.8^{\star \star \star}$ & $-19.5^{\star \star \star}$ & $11.4^{\star \star \star}$ \\
\hline Region & $8.4^{\star *}$ & -9.8 & $5.7^{\star \star}$ \\
\hline Father's education & $-4.6^{\star \star}$ & $22.1^{\star *}$ & $-2.4^{*}$ \\
\hline Father's occupation & 0.04 & 4.4 & -0.3 \\
\hline Born non-rural & 0.7 & & \\
\hline
\end{tabular}

17 For space reasons, we don't report the urban and rural regression results used for these decompositions. They are available from the authors on request. 
The Chinese Economic Transformation

\begin{tabular}{|c|c|c|c|}
\hline & Nationwide & Urban & Rural \\
\hline \multicolumn{4}{|c|}{ Share in discrimination effect (\%) } \\
\hline Age & -0.8 & -0.1 & -1 \\
\hline Own education & $-8.1^{\star \star}$ & -10.6 & $-5.6^{*}$ \\
\hline Own occupation & $-11.9^{* \star}$ & -31.3 & $-8.5^{\star \star \star}$ \\
\hline Migration & $2.2^{\star *}$ & $2.0^{*}$ & 2.3 \\
\hline Married & $37.8^{\star \star \star}$ & -13.7 & $58.5^{\star \star \star}$ \\
\hline Communist Party membership & -0.6 & 0.5 & -0.4 \\
\hline Region & $-15.9^{\star \star \star}$ & -10.4 & $-17.4^{\star \star \star}$ \\
\hline Father's education & 0.3 & -23.1 & 0.9 \\
\hline Father's occupation & -1.1 & 3.6 & -0.6 \\
\hline Born non-rural & -4.3 & & \\
\hline Constant & $102.2^{\star \star \star}$ & $183.3^{\star \star \star}$ & $72.0^{\star \star \star}$ \\
\hline
\end{tabular}

Sources: Survey of Chinese Women's Social Status (2010) and authors' calculations.

The results in Columns 2 and 3 reveal significant variations between the sources of the gender income gap in the urban and rural subsamples. For example, for the urban sample discrimination in fact contributes over 100 per cent to the gender income gap, because the difference-in-characteristics effect is negative (at -11.9 per cent) that is, it reduces the gap. This reduction stems from the fact that, unlike in the rural and nationwide samples, urban women are more likely to be employed in highly skilled work and are more likely to have fathers with higher levels of education, so both these factors reduce the gender income gap. ${ }^{18}$ Meanwhile, unlike in rural China, the urban results indicate that one's own education makes an insignificant contribution to the gap, reflecting the much closer average education levels across genders in urban areas.

Turning to the discrimination effect, the most striking differences are in the contributions from one's own education and occupation, as well as marriage. In the urban subsample, none of these make a significant contribution, whereas in the rural subsample, one's marital status increases the gap (accounting for 58.5 per cent of the discrimination effect), while occupational and educational 'efforts' work in women's favour.

18 Note that because the difference-in-characterstics' share is negative in the urban sample, a positive share implies that the variable in question reduces the gap. All other positive shares in Table 12.6 imply the opposite: that the variable works in favour of men. 
The finding that marriage makes a positive contribution to the gender income gap nationwide stems from the fact that it is significantly and positively associated with male income, but not with female income, as seen in Columns 3 and 4 of Table 12.2. It turns out that this is driven entirely by the rural subsample (as the marriage coefficient is insignificant in the urban subsample analysis). ${ }^{19}$

We can think of one reason why this might be the case. As our survey data reveals, 76 per cent of married males in rural China state that they never or rarely cook, 80 per cent never or rarely wash dishes, and 82 per cent never or rarely do washing or cleaning. This suggests a relatively weak position of rural women in intra-household bargaining relating to the time allocation for housework. We are not suggesting that urban Chinese women are 'taking it easy' at home either (for example, 65 per cent of married urban males never or rarely cook). But the results here indicate that the problem is more significant in rural China-a topic for further research.

\section{Conclusions}

This chapter has revealed that there is a serious lack of equal opportunity in the annual labour income of Chinese individuals. Unequal opportunities were shown to stem primarily from a substantial gender divide, but also from other circumstances that lie beyond an individual's control, including their region, father's occupation, father's education, birth cohort and rural or urban hukou status. We stress that we have not attributed causality to any of these circumstances, and we concede that biases possibly exist in all of them, due to omitted variables. While this means the decomposition results also need to be treated with caution, there seems no doubt that China faces a serious problem in terms of its gender income gap-with the contribution of gender to inequality of opportunity exceeding those of any other country for which comparable analysis exists.

We also investigated the role of five identifiable 'efforts'-one's own education and occupation, Communist Party membership, and migration and marital statusand demonstrated that an individual's 'efforts' are to a certain extent determined, or constrained, by their circumstances, in ways that differ significantly for men and women in the survey sample.

We took this analysis one step further by reinterpreting Equation 12.1 as an extended Mincer-type earnings equation and using Oaxaca-Blinder decompositions to understand the sources of the gender income gap at a more micro level. This revealed that discrimination-reflected in different coefficients on the male and female subsample regressions-dominated differences in characteristics, working

19 As per footnote 17, the urban and rural regression results are available from the authors on request. 
most strikingly against women in the rural sample, in terms of their income 'returns' to marriage. However, it is also clear that our explanation is far from complete; the contribution of the constant term significantly exceeded that of our observed variables, suggesting numerous other sources of gender discrimination in China's labour markets that we have not captured here.

In the meantime, the results presented in this chapter suggest a number of equal opportunity policies that could level the gender playing field in China in the foreseeable future. The fact that women's income, as well as their education and occupational choices, is more closely associated with their father's education and occupational status than men's suggests that it would be eminently reasonable for educational policies to specifically target girls from poor, rural families as a starting point for expanding their earnings opportunities later in life. Measures to assist young women to exit the agricultural sector and find off-farm employment would also likely improve their earnings potential in the future. Ongoing reforms to the hukou system of household registration to ensure that rural migrants are not discriminated against in urban areas, in terms of their access to jobs and social welfare and the pay cheques they receive, would also go some way towards equalising the opportunities they face with those of their urban counterparts.

Finally, the importance of marriage in the decompositions, and its different impact on the annual incomes of rural men and women in particular, points to the fact that China's 'gender discrimination' begins in the home. The gender divide in household chores revealed in our survey (and elsewhere, as in Zhang et al. 2008b) is indicative of just one of the costs that Chinese married women bear disproportionately, and it is little wonder that their annual income suffers as a result. Efforts to improve childcare systems and grant paternity, as well as maternity, leave are two obvious equal opportunity policies that could make a small dent in this regard, especially in rural areas. Even more important would be a cultural shift towards equal contributions by men and women to chores within the household - a challenge that is far from unique to China, but rather a global fight worth fighting.

\section{References}

Appleton, S., Knight, J., Song, L. and Xia, Q. (2009), The economics of Communist Party membership: The curious case of rising numbers and wage premium during China's transition, Journal of Development Studies 45(2): 256-75. doi.org/10.1080/ 00220380802264739 .

Arneson, R. (1989), Equality and equal opportunity for welfare, Philosophy Studies 56: 77-93. doi.org/10.1007/BF00646210.

Becker, G. (1974), A theory of social interactions, Journal of Political Economy 82(6): 1063-94. doi.org/10.1086/260265. 
Becker, G. (1976), The Economic Approach to Human Behavior, Chicago: University of Chicago Press.

Becker, G.S. (1991), Treatise on the Family, Cambridge, MA: Harvard University Press.

Bergmann, B. (1995), Becker's theory of the family: Preposterous conclusions, Feminist Economics 1(1): 141-50. doi.org/10.1080/714042218.

Björkland, A, Jäntti, M. and Roemer, J. (2012), Equality of opportunity and the distribution of long-run income in Sweden, Social Choice and Welfare 39(2-3): 675-96. doi.org/ 10.1007/s00355-011-0609-3.

Blinder, A.S. (1973), Wage discrimination: Reduced form and structural estimates, Journal of Human Resources 8(4): 436-55. doi.org/10.2307/144855.

Bourguignon, F., Ferreira, F. and Menéndez, M. (2007), Inequality of opportunity in Brazil, Review of Income and Wealth 53(4): 585-618. doi.org/10.1111/j.1475-4991. 2007.00247.x.

Bourguignon, F., Ferreira, F.H.G. and Menéndez, M. (2011), Inequality of opportunity in Brazil: A corrigendum, Review of Income and Wealth 59(3): 551-5. doi.org/10.1111/ roiw. 12045 .

Brunori, P., Ferreira, F.H.G. and Peragine, V. (2013), Inequality of opportunity, income inequality and economic mobility: Some international comparisons, IZA Discussion Paper No. 7155, January, Frankfurt am Main: Institute of Labor Economics. doi.org/ $10.1057 / 9781137333117 \_5$.

Checchi, D., Peragine, V. and Serlenga, L. (2010), Fair and unfair income inequalities in Europe, IZA Discussion Paper No. 5025, June, Frankfurt am Main: Institute of Labor Economics.

Chi, W. and Li, B. (2014), Trends in China's gender employment and pay gap: Estimating gender pay gaps with employment selection, Journal of Comparative Economics 42: 708-25. doi.org/10.1016/j.jce.2013.06.008.

Cohen, G. (1989), On the currency of egalitarian justice, Ethics 99: 906-44. doi.org/ $10.1086 / 293126$.

Connelly, R., Dong, X.-Y., Jacobsen, J. and Zhao, Y. (2018), The care economy in postreform China: Feminist research on unpaid work and paid work and well-being, Feminist Economics 24(2): 1-30. doi.org/10.1080/13545701.2018.1441534.

Cook, S. and Dong, X. (2011), Harsh choices: Chinese women's paid work and unpaid care responsibilities under economic reform, Development and Change 42(4): 947-65. doi.org/10.1111/j.1467-7660.2011.01721.x.

De Barros, R., Ferreira, F., Vega, J. and Chanduri, J. (2009), Measuring Inequality of Opportunities in Latin America and the Caribbean, Washington, DC: The World Bank. 
Démurger, S., Fournier, M. and Chen, Y. (2007), The evolution of gender earnings gaps and discrimination in urban China, 1988-95, The Developing Economies 45(1): 97-121. doi.org/10.1111/j.1746-1049.2007.00031.x.

Ding, S., Dong, X.-Y. and Maurer-Fazio, M. (2018), Childcare, household composition, Muslim ethnicity and off-farm work in rural China, Feminist Economics 24(2): 77-99. doi.org/10.1080/13545701.2017.1407032.

Dworkin, R. (1981a), What is equality? Part 1: Equality of welfare, Philosophy and Public Affairs 10: 185-246.

Dworkin, R. (1981b), What is equality? Part 2: Equality of resources, Philosophy and Public Affairs 10: 283-345.

Ferreira, F. and Gignoux, J. (2011), The measurement of inequality of opportunity: Theory and an application to Latin America, Review of Income and Wealth 57(4): 622-57. doi.org/10.1111/j.1475-4991.2011.00467.x.

Ferreira, F. and Peragine, V. (2015), Equality of opportunity, IZA Discussion Paper No. 8994, April, Frankfurt am Main: Institute of Labor Economics.

Fincher, L.H. (2016), Leftover Women: The resurgence of gender inequality in China, 2nd edn, London: Zed Books.

Golley, J. (2007), The Dynamics of Regional Development in China: Market nature, state nurture, Cheltenham, UK: Edward Elgar Publishing.

Golley, J. and Kong, S.T. (2018), Inequality of opportunity in China's educational outcomes, China Economic Review 51(October): 116-28. doi.org/10.1016/j.chieco.2016.07.002.

Golley, J. and Tyers, R. (2012), Gender rebalancing in China, Asian Population Studies 10(2): 125-43. doi.org/10.1080/17441730.2014.902159.

Gustafsson, B., Li, S. and Sicular, T. (eds) (2008), Inequality and Public Policy in China, New York: Cambridge University Press. doi.org/10.1017/CBO9780511510922.

Hannum, E., Kong, P. and Zhang, Y. (2009), Family sources of educational gender inequality in rural China: A critical assessment, International Journal of Educational Development 29(5): 474-86. doi.org/10.1016/j.ijedudev.2009.04.007.

Hederos, K., Jäntti, M. and Lindahl, L. (2017), Gender and inequality of opportunity in Sweden, Social Choice Welfare 49(3-4): 605-35. doi.org/10.1007/s00355-017-1076-2.

Jusot, F., Tubeuf, S. and Trannoy, A. (2013), Circumstances and efforts: How important is their correlation for the measurement of inequality of opportunity in health?, Health Economics 22(12): 1470-95. doi.org/10.1002/hec.2896.

Kanbur, R. and Zhang, X. (2005), Fifty years of regional inequality in China: A journey through central planning, reform and openness, Review of Development Economics 9(1): 87-106. doi.org/10.1111/j.1467-9361.2005.00265.x. 
Knight, J. (2014), Inequality in China: An overview, World Bank Research Observer 29(1): 1-19. doi.org/10.1093/wbro/lkt006.

Knight, J., Shi, L. and Wan, H. (2016), The increasing inequality of wealth in China, 20022013, Department of Economics Discussion Paper Series No. 816, Oxford: University of Oxford.

Li, C. (2010), Expansion of higher education and inequality of opportunity in education: A study of the effect of the expansion policy on equalisation of educational attainment, [in Chinese], Sociological Studies 3: 82-113.

Li, S., Satō, H. and Sicular, T. (2013), Rising Inequality in China: Challenges to a harmonious society, Cambridge: Cambridge University Press. doi.org/10.1017/CBO9781139035057.

Li, S., Song, J. and Liu, X. (2011), Evolution of the gender wage gap among China's urban employees, Social Sciences in China 32(3): 161-80. doi.org/10.1080/02529203.2011. 598307.

Liu, L., Dong, X.-Y. and Zheng, X. (2010), Parental care and married women's labour supply in urban China, Feminist Economics 16(3): 169-92. doi.org/10.1080/1354570 1.2010 .493717$.

Marrero, G. and Rodríguez, J.G. (2012), Inequality of opportunity in Europe, Review of Income and Wealth 58(4): 597-620. doi.org/10.1111/j.1475-4991.2012.00496.x.

Martinez, A., Rampino, T., Western, M., Tomaszewski, W. and Roque, J.D. (2017), Estimating the contribution of circumstances that reflect inequality of opportunity, Economic Papers 36(4): 380-400. doi.org/10.1111/1759-3441.12184.

Meng, X. (1998), Male-female wage discrimination and gender wage discrimination in China's rural industrial sector, Labour Economics 5: 67-89. doi.org/10.1016/S09275371(97)00028-6.

Ministry of Foreign Affairs (2015), Xi Jinping attends and addresses global leaders' meeting on gender equality and women's empowerment, stressing to promote women's allround development and jointly construct and share wonderful world, Press release, 29 September, Beijing, available from: www.fmprc.gov.cn/mfa_eng/topics_665678/ xjpdmgjxgsfwbcxlhgcl70znxlfh/t1302736.shtml.

Oaxaca, R. (1973), Male-female wage differentials in urban labor markets, International Economic Review 14(13): 693-709. doi.org/10.2307/2525981.

Piketty, T., Yang, L. and Zucman, G. (2017), Capital accumulation, private property and rising inequality in China, 1978-2015, NBER Working Paper No. 23368, Cambridge, MA: National Bureau of Economic Research. doi.org/10.3386/w23368.

Pollak, R. (2003), Gary Becker's contribution to family and household economics, Review of Economics of the Household 1(1): 111-41. doi.org/10.1023/A:1021803615737.

Roemer, J. (1993), A pragmatic theory of responsibility for the egalitarian planner, Philosophy and Public Affairs 22: 146-66. 
Roemer, J. (1998), Equality of Opportunity, Cambridge, MA: Harvard University Press.

Rozelle, S., Dong, X., Zhang, L. and Mason, A. (2002), Gender wage gaps in post-reform rural China, Pacific Economic Review 7(1): 157-79. doi.org/10.1111/1468-0106.00009.

Shu, X. and Bian, Y. (2003), Market transition and the gender gap in earnings in urban China, Social Forces 81(4): 1107-45. doi.org/10.1353/sof.2003.0070.

Shu, X., Zhu, Y. and Zhang, Z. (2007), Global economy and gender inequalities: The case of the urban Chinese labour market, Social Science Quarterly 88(5): 1307-32. doi.org/10.1111/j.1540-6237.2007.00504.x.

Sicular, T., Yue, X., Gustafsson, B. and Shi, L. (2007), The urban-rural income gap and inequality in China, Review of Income and Wealth 53(1): 93-126. doi.org/10.1111/ j.1475-4991.2007.00219.x.

Singh, A. (2012), Inequality of opportunity in earnings and consumption expenditure: The case of Indian men, Review of Income and Wealth 58(1): 79-106. doi.org/10.1111/ j.1475-4991.2011.00485.x.

Song, J., Sicular, T. and Gustafsson, B. (2017), China's urban gender wage gap: A new direction, CHCP Working Paper Series No. 2017-23, London, Ontario: Centre for Human Capital and Productivity.

Song, Y. and Dong, X.-Y. (2018), Childcare costs and migrant and local mothers' labor force participation in urban China, Feminist Economics 24(2): 122-46. doi.org/10.1080/135 45701.2017.1398405.

$\mathrm{Su}, \mathrm{B}$. and Heshmati, A. (2011), Analysis of gender wage differential in China's urban labor market, IZA Discussion Paper Series No. 6252, Frankfurt am Main: Institute of Labor Economics.

Tang, Y. (2016), Class and Gender: Social stratification of women in contemporary urban China, Cambridge: Cambridge Scholars Publication.

Wang, M. and Cai, F. (2008), Gender earnings differential in urban China, Review of Development Economics 12(2): 442-54. doi.org/10.1111/j.1467-9361.2008.00450.x.

Woolley, F. (1996), Getting the better of Becker, Feminist Economics 2(1): 114-20. doi.org/ $10.1080 / 738552692$.

Xie, K. (2017), Her China dream: The aspirations of China's privileged daughters, Discover Society, 9 September, [Online], available from: discoversociety.org/2017/09/05/her-chinadream-the-aspirations-of-chinas-privileged-daughters/?utm_source=SupChina\&utm_ campaign=e859050b63-20170907-372+TheDPRK'Students-cum-spies\&utm_ medium=email\&utm_term=0_caef3ab334-e859050b63-164871129.

Zhang, J., Han, J., Liu, P.-W. and Zhao, Y. (2008a), Trends in the gender earnings differential in urban China, 1988-2004, Industrial and Labor Relations Review 61(2): 224-43. doi.org/10.1177/001979390806100205. 
Zhang, J., Pang, X., Zhang, L., Medina, A. and Rozelle, S. (2012), Gender inequality of education in China: A meta-regression analysis, REAP Working Paper 239, May, Stockholm: Resources and Energy Analysis Programme.

Zhang, Q.F. (2013), Gender disparities in self-employment in urban China's market transition: Income inequality, occupational segregation and mobility processes, China Quarterly 215(September): 744-63. doi.org/10.1017/S030574101300074X.

Zhang, Y., Hannum, E. and Wang, M. (2008b), Gender-based employment and income differences in urban China: Considering the contributions of marriage and parenthood, Social Forces 86(4): 1529-60. doi.org/10.1353/sof.0.0035.

Zhang, Y., Kao, G. and Hannum, E. (2007), Do mothers in rural China practice gender equality in educational aspirations for their children?, Comparative Education Review 51(2): 131-57. doi.org/10.1086/512023.

Zhang, Z. and Chen, Q. (2014), The expansion of higher education admissions and the gender equalization of higher education opportunity: An empirical study based on Chinese General Social Survey (CGSS2008) data, The Journal of Chinese Sociology 1: 1-19. doi.org/10.1186/s40711-014-0001-7.

Zhou, Y. and Song, L. (2016), Income inequality in China: Causes and policy responses, China Economic Journal 9(2): 186-208. doi.org/10.1080/17538963.2016.1168203. 
This text is taken from The Chinese Economic Transformation: Views from Young Economists, edited by Ligang Song, Yixiao Zhou and Luke Hurst, published 2019 by ANU Press, The Australian National University, Canberra, Australia.

doi.org/10.22459/CET.2019.12 